\title{
Reproductive isolation among three populations of the genus Grammostola from Uruguay (Araneae, Theraphosidae)
}

\author{
Rodrigo Postiglioni \& Fernando G. Costa
}

Laboratorio de Etología, Ecología y Evolución, Instituto de Investigaciones Biológicas Clemente Estable, Av. Italia 3318, Montevideo, Uruguay. (posti@iibce.edu.uy)

\begin{abstract}
Ethological isolation of individuals from three allopatric Grammostola populations of Uruguay, G. iheringi (Keyserling, 1891), G. mollicoma (Auserer, 1875) northern population and G. mollicoma southern population, was tested under laboratory conditions. Grammostola iheringi behaved as a reproductive isolated species, whereas the two populations of G. mollicoma did not show ethological isolation between them. However, ecological isolating reproductive mechanisms could be acting on G. mollicoma populations. Artificial burrows seem to be important for reproductive isolation in these species.
\end{abstract}

KEYWORDS. Grammostola iheringi, Grammostola mollicoma, reproductive isolation, ethological isolation.

RESUMEN. Aislamiento reproductivo entre tres poblaciones del género Grammostola de Uruguay (Araneae, Theraphosidae). Se testeó bajo condiciones de laboratorio, el aislamiento etológico de individuos de poblaciones alopátridas de Grammostola de Uruguay, G. iheringi (Keyserling, 1891), G. mollicoma (Auserer, 1875) población norte y G. mollicoma población sur. Grammostola iheringi se comportó como una especie aislada, mientras que las dos formas de Grammostola no mostraron aislamiento etológico. Sin embargo, mecanismos de aislamiento reproductivo ecológico podrían estar actuando entre las poblaciones de G. mollicoma. Las cuevas artificiales serían importantes para el aislamiento reproductivo de estas especies.

PALABRAS-CLAVE. Grammostola iheringi, Grammostola mollicoma, aislamiento reproductivo, aislamiento etológico.

Although studies on reproductive biology of araneomorph spiders were widely developed during the past century (FoElIX, 1996), reports on mygalomorphs in general and particularly on the large theraphosids (commonly known as tarantulas), are scarce (review in Costa \& Pérez-Miles, 2002). The genus Grammostola comprises species of large bodied tarantulas $(20-30 \mathrm{~mm}$ carapace length). Two allopatric species have had their reproductive biology studied in Uruguay: G. iheringi (Keyserling, 1891), which have been reported only at neighboring areas of the Quebrada de los Cuervos, province of Treinta y Tres ( $\left.35^{\circ} 57^{\prime} \mathrm{S}, 54^{\circ} 31^{\prime} \mathrm{W}\right)$, and $G$. mollicoma (Auserer, 1875) which is widely distributed throughout the country (Costa \& Pérez-Miles, 2002; Fig. 1). Two allopatric populations of G. mollicoma are found (Fig. 1), one in northern and other in southern Uruguay (although the limits between these two populations are not clearly defined). Moreover, there are some morphological differences between individuals from the two populations. In the southern population, individuals have a round-shaped abdomen, are brown-colored and have long, red hairs located ventrally on coxae, femora, and patellae of the pedipalps and legs. Conversely, individuals from the northern population have an oval abdomen, are black-colored and lack those red hairs on pedipalps and legs. Recently collected individuals of the southern population living at the North of Río Negro river (Fig. 1) suggest that zones close to latitude $33^{\circ} 10^{\prime} \mathrm{S}$ and not the Río Negro river basin would be the limit of northern and southern populations. These data would support the occurrence of two different spider species. However, previous preliminary reports had found no ethological isolation between these populations in laboratory open arenas (PÉREZ-Miles \& CostA, 1992). This contradiction needs to be elucidated with more data.

On the other hand, the only known population of G. iheringi from Uruguay is located in an intermediate zone between the populations of G. mollicoma (Fig. 1). In fact, individuals of the southern population were found $5 \mathrm{~km}$ from the Quebrada de los Cuervos, while individuals of the northern population were never found at this zone. However, some of these areas have not been exhaustively sampled, especially at the north of this location (Fig. 1).

Males of Grammostola spp. live 30-45 months in the field after the last molt. We deduce that the reproductive period is extended throughout the year (Costa \& Pérez-Miles, 2002). Populations of large spiders, mainly G. iheringi, are being threatened by human impact or pet commerce (Costa \& Pérez-Miles, 2002). Moreover, most species have a slow growth rate, taking ten years to reach adulthood (Costa \& PÉrez-Miles, 2002). For these reasons, we decided to limit the captures to just few individuals.

In this paper, we experimentally tested ethological reproductive isolation among the three populations under laboratory conditions by using different kinds of arenas (with or without burrows). Results provide first data about ethological isolation among closely related species of tarantulas, corroborating previous data by PÉREZ-MILES $\& \operatorname{CosTA}(1992)$.

\section{MATERIAL AND METHODS}

Three males and four females of $G$. iheringi were collected in Quebrada de los Cuervos and neighboring areas, in the province of Treinta y Tres. Two males and 


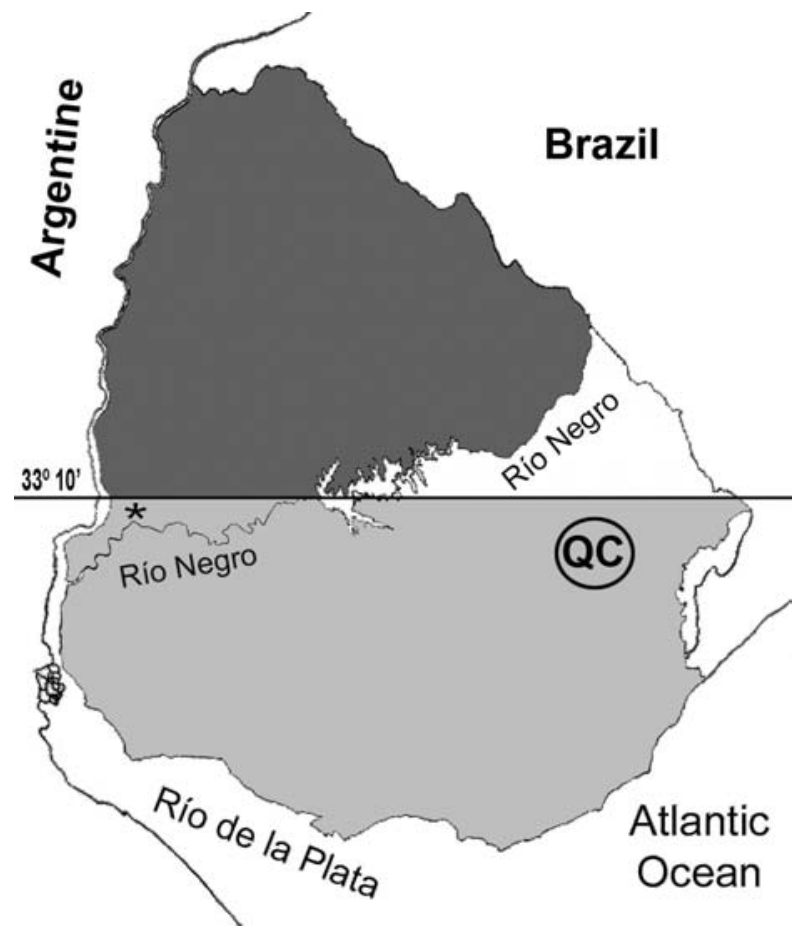

Fig. 1. Distribution of populations of Grammostola spp. in Uruguay. The dark grey corresponds to the northern population of $G$. mollicoma, whereas the light grey indicates the southern population. The white area corresponds to the absence of records for the genus. The horizontal line corresponds to the latitude which would delimit northern and southern populations of $G$. mollicoma. The asterisk indicates the recent records of individuals of the southern population of G. mollicoma at the north of the Río Negro river. QC stands for Quebrada de los Cuervos, the unique location where $G$. iheringi is found in Uruguay.

nine females of the southern morph of G. mollicoma were collected in the provinces of Durazno, Lavalleja, Maldonado, Montevideo and Rocha. Three males and six females of the northern morph were collected in the provinces of Artigas, Paysandú, Rivera, Salto and Tacuarembó. In the laboratory, individuals were reared in rectangular plastic cages ( $14 \times 20 \mathrm{~cm}$ base, $9 \mathrm{~cm}$ high) containing soil and water provision, and were fed ad libitum on cockroaches (Blaptica dubia (Serville, 1839)). Room temperature ranged between $18.5^{\circ} \mathrm{C}$ and $27{ }^{\circ} \mathrm{C}$ (mean $\pm \mathrm{SD}=21.6 \pm 1.1^{\circ} \mathrm{C}$ ) and, despite the wide variation, we consider that tarantulas of the three populations are exposed to similar conditions in the field along the year.

We carried out three series of experiments in cages $\left(0.13 \mathrm{~m}^{2}\right.$ base, $35 \mathrm{~cm}$ high $)$ with a layer of soil of approximately $8 \mathrm{~cm}$ : (A) a male was carefully placed in the arena on the silken layer left by the female, which was removed from the cage immediately before the introduction of this male; (B) a male was placed on the silken layer of a female, which remained inside the cage; (C) similar to the anterior, but when the male was placed in the cage, the female was inside an artificial burrow. The burrow of each female was built against a glass wall, excavating the soil and using a stone as a roof. This burrow simulated natural conditions and allowed the observation through the glass. Females were placed in the experimental cages at least $24 \mathrm{~h}$ before trials. Each trial started when the male touched the substrate with his palps and ended after a 30 min-period (trial A) or when the mating occurred (trials B and C). Body vibrations and palpal drumming as a starting of male sexual response, occurrence of mating and also rejection by female were registered in direct observations, and in some cases video-taped.

Experiments were carried out during the June August period of 2002 and 2003. Individuals were randomly assigned to all the experimental groups. Males of each population were exposed to females from the three populations, at the three experimental situations (27 experiments). Each experiment was repeated twice using different individuals, completing 54 trials (see Tab. I). Individuals were reused at least 24 hours after the previous experiment. Specimens are still alive and will be deposited in the Entomological Collection of the School of Sciences, Montevideo.

\section{RESULTS}

Males of the southern population of G. mollicoma courted on silk tracks left by the three female populations. Silk tracks from the southern population seemed to elicit sexual responses in the three populations of males. Males of northern population of $G$. mollicoma and males of $G$. iheringi showed minor or no sexual responses (palpal drumming and body vibrations) to female silk tracks, including those left by females of their own species (Tab. I). In male-female encounters in the open field, males of the southern population of G. mollicoma mated with females from the two populations of the species, but not with $G$. iheringi. Females of the southern population of G. mollicoma copulated with males of the three populations. Conversely, females of the northern population mated only with $G$. mollicoma males. Grammostola iheringi females accepted only a conspecific mate. When females remained in burrows, only conspecific mates were accepted by $G$. iheringi, but G. mollicoma females accepted both southern and northern males (Tab. I).

Courtship of males showed similar characteristics among the three populations, involving body vibrations caused by leg III movements and palpal drumming. Tapping with the forelegs was also observed in the southern population of G. mollicoma and in G. iheringi, followed by body vibrations and palpal drumming sequences. Males vigorously hit usually legs I and sometimes with legs II or both against the substrate. Grammostola iheringi males also included bites against female fangs from the three populations, performing them sometimes before and usually after mating. This aggressive biting behavior included the following sequence: first, male and female interweaved forelegs and then both individuals opened the chelicerae and fangs, making a rhomboid-shaped space between each other; then the male pressed the female fangs with his own ones and stepped back, making the same figure once again. This sequence was repeated many times.

All males clasped the female fangs with the tibial apophyses of the forelegs, and tapped females 
Table I. Number of males that courted (experiment A) or mated (B and C) in double trial experiments.

\begin{tabular}{|c|c|c|c|c|c|c|c|c|c|}
\hline Male Female & \multicolumn{3}{|c|}{$\begin{array}{c}\text { G. mollicoma } \\
\text { southern population }\end{array}$} & \multicolumn{3}{|c|}{$\begin{array}{l}\text { G. mollicoma } \\
\text { northern population }\end{array}$} & \multicolumn{3}{|c|}{ G. iheringi } \\
\hline & A & $\mathrm{B}$ & $\mathrm{C}$ & A & $\mathrm{B}$ & $\mathrm{C}$ & A & $\mathrm{B}$ & $\mathrm{C}$ \\
\hline $\begin{array}{l}\text { G. mollicoma } \\
\text { southern population }\end{array}$ & 2 & 2 & 2 & 1 & 2 & 2 & 2 & 0 & 0 \\
\hline $\begin{array}{l}\text { G. mollicoma } \\
\text { northern population }\end{array}$ & 2 & 2 & 1 & 0 & 2 & 2 & 0 & 0 & 0 \\
\hline G. iheringi & 2 & 2 & 0 & 1 & 0 & 0 & 0 & 1 & 1 \\
\hline
\end{tabular}

spasmodically with legs II. Mating showed the typical mygalomorph position (male raising female and inserting palps beneath her). Males finished mating without receiving attacks from the females.

\section{DISCUSSION}

Results confirm that ethological reproductive isolation does not occur between southern and northern populations of $G$. mollicoma, which could be geographical variants of the species. Considering that males of the two populations of G. mollicoma are present during the whole year at the field (which suggests no differences in mating seasons), we conclude that other mechanism of reproductive isolation could be occurring, for example different habitat preference as an ecological mechanism. Due to our poor knowledge on distribution of these populations of $G$. mollicoma, especially in the intermediate zone, we cannot be sure if a contact zone between them really exists. If it does not exist, it would be supporting the hypothesis of two different species.

Grammostola iheringi showed an effective ethological reproductive isolation with the other two populations after physical contact. According to our previous experience, ethological reproductive isolation under laboratory conditions does not seem a very effective mechanism in tarantulas compared to other spiders as lycosids (Uetz \& Denterlein, 1979; Costa \& Capocasale, 1984). Selectivity showed by G. iheringi would suggest the occurrence of a well-developed ethological isolating mechanism, which keeps this species separated with other related tarantulas. Unfortunately, valuable information related to the progeny from mated females is not available, because it is very difficult to obtain it under laboratory conditions in theraphosids (but see Costa \& PÉREZ-MiLes, 1992, 2002).

Leg tapping with forelegs during courtship was not indicated by Pérez-Miles \& Costa (1992) for these species and is described here for the first time. A similar behavior had been described by BAERG (1958), PRENTICE (1997) and Shillington \& Verrell (1997) for Aphonopelma spp. males. These last authors suggested that this behavior could be generating seismic signals. For the genus Grammostola, a behavior that resembled leg tapping was unclearly described by BRAzIL \& VELLARD (1926). Costa \& PÉREZ-MiLes (2002) observed leg tapping only in females of Acanthoscurria suina Pocock, 1903 and Eupalaestrus weijenberghi (Thorell, 1894). QUIRICI \& CosTa (2005) suggest that leg tapping in A. suina and $E$. weijenberghi acts as seismic signals of sexual readiness to mating. Here, we conclude that leg tapping could be acting as communicatory signals in a sexual context, maybe using a seismic and/or acoustic channel.

When artificial burrows were available, females occupied them and increased their possibilities of selecting mates because mating is not possible inside the burrow, it only occurs outside or near the burrow entrance. Then if the female remains inside the burrow, mating would not be possible and the male can be considered rejected. For example, in male G. iheringi vs. female G. mollicoma encounters, two interspecific matings were observed in open field but none when a burrow was present. It suggests that when the female remains inside her burrow, the male who is not chosen for mating cannot be cohersive and mating does not occur. This situation would resemble natural conditions and we advise it for similar experiments.

Grammostola iheringi male bites are very conspicuous and seem to be ritualized, because they were performed in face-to-face position, with no damage observed. Costa \& PÉREZ-Miles (2002) described this behavior only in a male of this species, and no previous data were found for other theraphosids. Frontal bite behavior seems to be incorporated into the male courtship of this species, because all the males of $G$. iheringi performed it in our experiments on the females from the three populations, but it was not observed by males of the two G. mollicoma populations on females of $G$. iheringi. This conspicuous behavior has probably evolved from an aggressive context and was later incorporated to the species-specific ritualized repertoire. Quantifying this behavior and its consequences on mating acceptance and/or fecundation of eggs is a true challenge for future studies, mainly in the field.

Acknowledgments. Thanks to Fernando Pérez-Miles (School of Sciences, Montevideo), who critically read the first draft of the manuscript. Thanks also to Anita Aisenberg (IIBCE), for improving the English. Soledad Ghione, Tony Mignone and Carlos Toscano-Gadea (IIBCE) helped us to collect the tarantulas. We also acknowledge two anonymous reviewers for improving the last version of this manuscript.

\section{REFERENCES}

BAERG, W. J. 1958. The tarantula. Lawrence, University of Kansas. 88p.

Brazil, V. \& Vellard, J. 1926. Contribuição ao estudo do veneno das aranhas. II. Memórias do Instituto Butantan 3:243295.

Costa, F. G. \& Capocasale, R. M. 1984. Lycosa carbonelli sp. nov., una etoespecie gemela, simpátrida de Lycosa thorelli (Keyserling) (Araneae, Lycosidae). Journal of Arachnology 
11(3):423-431.

Costa, F. G. \& Pérez-Miles, F. 1992. Notes on mating and reproductive success of Ceropelma longisternalis (Araneae, Theraphosidae) in captivity. Journal of Arachnology 20(2):129-133.

2002. Reproductive biology of Uruguayan theraphosids (Araneae, Mygalomorphae). Journal of Arachnology 30(3):571-587.

Foelix, R. 1996. Biology of spiders. New York, Oxford University. $336 \mathrm{p}$.

Pérez-Miles, F. \& Costa, F. G. 1992. Interacciones intra e intersexuales en Grammostola mollicoma (Araneae, Theraphosidae) en condiciones experimentales. Boletín de la Sociedad Zoológica del Uruguay 7:71-72.
Prentice, T. R. 1997. Theraphosidae of the Mojave desert west and north of the Colorado River (Araneae, Mygalomorphae, Theraphosidae). Journal of Arachnology 25(2):137-176.

Quirici, V. \& CostA, F. G. 2005. Seismic communication during courtship in two burrowing tarantula spiders: an experimental study on Eupalaestrus weijenberghi and Acanthoscurria suina. Journal of Arachnology 33(1):159-166.

Shillington, C. \& Verrell, P. 1997. Sexual strategies of a North American 'Tarantula' (Araneae: Theraphosidae). Ethology 103(7):588-598.

Uetz, G. W. \& Denterlein, G. 1979. Courtship behavior, habitat, and reproductive isolation in Schizocosa rovneri Uetz and Dondale (Araneae, Lycosidae). Journal of Arachnology 7(2):121-128.

Recebido em fevereiro de 2005. Aceito em dezembro de 2005. ISSN 0073-4721

Artigo disponível em: www.scielo.br/isz 